\title{
HUMAN-AUTOMATION INTERACTION IN LAW: MAPPING LEGAL DECISIONS, COGNITIVE PROCESSES, AND AUTOMATION LEVELS
}

\author{
Dovilè Petkevičiūtè-Barysienė \\ Institute of Psychology, Vilnius University (Lithuania)
}

\begin{abstract}
Legal technologies not only create new ways for accessing and providing legal services, but also transform the roles of legal practitioners. Major area of the application of legal technologies are courts. Some courts, e.g., in Austria, are already using legal technologies, Germany, Brazil, France, Netherlands, Russia and others are developing legal technologies. Both lawyers and users of legal services expect automated solutions to outperform people with efficiency, objectivity and impartiality. Although perception of various characteristics of legal technologies is crucial to their implementation and use, research on the perceived characteristics of the automated processes in legal contexts have just begun. One of the major obstacles to this research is lack of comprehensive understanding what legal actions could be or already are meaningfully automated, and to what extent. The aim of this study is to map decision making stages, and automation levels, and information processing features of legal activities related to (pre)trial processes.

Major legal decisions and judgments related to trial processes are identified during the consultations with legal practitioners (e.g., prosecutor, judge). Next, legal activities were described and arranged according to four-stage decision making process: information acquisition, information analysis, decision selection and decision implementation. A taxonomy of levels of automation (LOA) was customized to fit legal decision making and applied to describe each major legal activity. Lastly, dual-process model of information processing was used to delineate possible roles of intuitive and rational information processing taking place during (pre)trial decision making as they could be related to human-automation interaction.

Automation level analysis provides systematic approach to interaction between humans and algorithms, along with some groundwork for the research of legal technology perceived fairness and acceptance. 10 legal activities which apply both to judge's and prosecutor's (potentially any other lawyer's) legal work were discerned. The application of adapted LOA (5 levels) provided some insights into legal decision making as it allows to place existing technology, test the trust in technology threshold, and have more tangible view of automation in legal activities. Moreover, a modified hybrid default-interventionist model is proposed. It brings even more depth into analysis by specifying the role of "legal" and "heuristic" intuitions as well as the part rationalization plays in potential bias sources and formation.
\end{abstract}

Keywords: Legal decision making, legal technology, levels of automation, dual information processing, legal intuition.

\section{Introduction}

Legal technologies are rapidly changing the accessibility of legal services and functions of the legal practitioners. The number of technological products for lawyers is growing swiftly. Lawyers themselves feel overwhelmed and worried about their role in the technological progress (e.g., Morison \& Harkens, 2019). However, scientific research is towing at the back of the progress. Additionally, psychological research on LegalTech is lacking guidance - there is no proposed taxonomy or description of the automation of legal processes related to court, researchers are left with only publicly available information about some of the existing legal technologies. Categorization is especially important for research - without it, disparate studies of some existing technologies would not provide sufficient insight into perception of legal technologies, and could not support their acceptance. Therefore, the aim of this study is to analyze decision making stages, and automation levels, and information processing features of legal activities related to (pre)trial processes.

\section{Method}

Firstly, to obtain major legal activities related to trial processes, 6 consultations with lawyers were conducted ( 1 civil case judge, 2 administrative court judge's assistants, 2 prosecutors, 1 legal 
scholar). Each lawyer was asked to describe the most important decisions and processes related to trial and pretrial (for prosecutors). The author is very thankful to all lawyers who contributed to the study, and incredibly grateful to yet another lawyer, who helped to discern and describe the most important steps in judicial decision making.

Next, the legal decision making steps were described and rearranged according to decision making stages. In this paper Parasuraman, Sheridan, and Wickens (2000) notion of four broad functions of decision making are used: information acquisition, which is defined as gathering and filtering, prioritizing, and understanding the data; information analysis (B) - analyzing, interpreting data and making inferences, prognoses; decision selection (C) - prioritizing/ranking decision alternatives; and, finally, decision implementation (D), which is defined as actual execution of the choice (e.g., writing-up and submitting the relevant document).

Further, a taxonomy of levels of automation was customized to fit legal decision making. Out of all taxonomies in systematic analysis (see Vagia et al., 2016), the taxonomy where decision making stages are also incorporated is the one suggested by Proud, Hart, and Mrozinski (2003). Although stages of decision making in Proud et al. (2003) are described in a slightly different way - observe, orient, decide, and act, they correspond to Parasuraman et al. (2000) categorization very well. Proud et al. (2003) presented 8-level LOA, however a 5-level LOA was more suitable to our purposes (see Table 1). Each level of automation for each legal activity was described.

Table 1. Levels of automation adapted to be applied to legal decision making related to (pre)trial (adapted from Proud et al., 2003).

\begin{tabular}{|c|c|c|c|c|}
\hline \multirow{2}{*}{$\begin{array}{l}\text { Level of } \\
\text { automation }\end{array}$} & \multicolumn{4}{|l|}{ Decision making stage } \\
\hline & $\begin{array}{l}\text { Information } \\
\text { acquisition }\end{array}$ & Information analysis & Decision selection & Decision implementation \\
\hline 1 (manual) & $\begin{array}{l}\text { Human is the only } \\
\text { source for gathering } \\
\text { and filtering, } \\
\text { prioritizing and } \\
\text { understanding all } \\
\text { data. }\end{array}$ & $\begin{array}{l}\text { Human is responsible for } \\
\text { analyzing all data, making } \\
\text { predictions, and } \\
\text { interpretation of the data }\end{array}$ & $\begin{array}{l}\text { The computer does not } \\
\text { assist in or perform } \\
\text { ranking tasks. Human } \\
\text { must do it all }\end{array}$ & $\begin{array}{l}\text { Human alone can execute } \\
\text { decision }\end{array}$ \\
\hline 2 (low) & $\begin{array}{l}\text { The computer } \\
\text { gathers, displays and } \\
\text { offers filtering }\end{array}$ & $\begin{array}{l}\text { The computer analyzes the } \\
\text { data and makes } \\
\text { predictions, though the } \\
\text { human is responsible for } \\
\text { interpretation of the data }\end{array}$ & $\begin{array}{l}\text { Both human and } \\
\text { computer perform } \\
\text { ranking tasks, results } \\
\text { from the human are } \\
\text { considered prime }\end{array}$ & $\begin{array}{l}\text { The computer executes } \\
\text { decision after human } \\
\text { approval. }\end{array}$ \\
\hline $\begin{array}{l}3 \text { (inter- } \\
\text { mediate) }\end{array}$ & $\begin{array}{l}\text { The computer } \\
\text { gathers, displays and } \\
\text { offers filtering as } \\
\text { well as highlights } \\
\text { relevant information } \\
\text { for the human }\end{array}$ & $\begin{array}{l}\text { The computer overlays } \\
\text { predictions with analysis } \\
\text { and interprets the data. The } \\
\text { human shadows the } \\
\text { interpretation for } \\
\text { contingencies. }\end{array}$ & $\begin{array}{l}\text { The computer } \\
\text { performs ranking tasks. } \\
\text { All results, including } \\
\text { "why" decisions were } \\
\text { made, are displayed to } \\
\text { the human }\end{array}$ & $\begin{array}{l}\text { The computer allows the } \\
\text { human a context-dependent } \\
\text { restricted time to veto } \\
\text { before execution. Human } \\
\text { shadows for contingencies }\end{array}$ \\
\hline 4 (high) & $\begin{array}{l}\text { The computer } \\
\text { gathers, filters, and } \\
\text { prioritizes } \\
\text { information } \\
\text { displayed to the } \\
\text { human }\end{array}$ & $\begin{array}{l}\text { The computer analyzes, } \\
\text { predicts, interprets, and } \\
\text { integrates data into a result } \\
\text { which is only displayed to } \\
\text { the human if result fits } \\
\text { programmed context } \\
\text { (context dependent } \\
\text { summaries) }\end{array}$ & $\begin{array}{l}\text { The computer } \\
\text { performs ranking tasks. } \\
\text { The computer } \\
\text { performs final ranking } \\
\text { and displays a reduced } \\
\text { set of ranked options } \\
\text { without displaying } \\
\text { "why" decisions were } \\
\text { made }\end{array}$ & $\begin{array}{l}\text { The computer executes } \\
\text { automatically and only } \\
\text { informs the human if } \\
\text { required by context. It } \\
\text { allows for override ability } \\
\text { after execution. Human is } \\
\text { shadow for contingencies }\end{array}$ \\
\hline 5 (full) & $\begin{array}{l}\text { The computer } \\
\text { gathers, filters, and } \\
\text { prioritizes data } \\
\text { without displaying } \\
\text { any information }\end{array}$ & $\begin{array}{l}\text { The computer predicts, } \\
\text { interprets, and integrates } \\
\text { data into a result which is } \\
\text { not displayed to the human }\end{array}$ & $\begin{array}{l}\text { The computer } \\
\text { performs ranking tasks. } \\
\text { The computer } \\
\text { performs final ranking, } \\
\text { but does not display } \\
\text { results }\end{array}$ & $\begin{array}{l}\text { The computer executes } \\
\text { automatically and does not } \\
\text { allow any human } \\
\text { interaction }\end{array}$ \\
\hline
\end{tabular}

The last step in mapping legal decisions, cognitive processes, and automation levels was to specify the role of dual information processing - intuitive and rational. Dual process models (e.g., Kahneman, 2011) describe and predict human reasoning and decision making based on the assumption that there are two different types of thinking, popularly referred to as System 1 and System 2 (also - intuitive and deliberate, intuitive and rational, Type 1 and Type 2, reflexive and reflective 
processing). Type 1 (T1) processing is believed to be fast, effortless, automatic and autonomous, and Type 2 (T2) - slower, effortful, deliberate and resource demanding (e.g., Pennycook, Fugelsang, \& Koehler, 2015). For this task, a fairly new hybrid default-interventionist model of dual processing (Bago \& De Neys, 2020; De Neys, 2018; Pennycook et al., 2015) was used.

\section{Results}

10 legal activities which apply both to judge's and prosecutor's (potentially any other lawyer's) legal work with examples and decision making stages are presented in Table 2.

Table 2. Major legal activities and corresponding decision making stages.

\begin{tabular}{|c|c|c|c|}
\hline Activity & Judge & Prosecutor & $\begin{array}{l}\text { Decision } \\
\text { making } \\
\text { stage }\end{array}$ \\
\hline $\begin{array}{l}\text { Getting acquainted with the } \\
\text { given information }\end{array}$ & $\begin{array}{l}\text { e.g., getting acquainted with the } \\
\text { complaint (reading it) }\end{array}$ & $\begin{array}{l}\text { e.g., getting acquainted with the } \\
\text { notice of offence }\end{array}$ & $\mathrm{A}$ \\
\hline $\begin{array}{l}\text { Information search and analysis } \\
\text { (legislation, case law, additional } \\
\text { sources of information) }\end{array}$ & $\begin{array}{l}\text { e.g., search and analysis of relevant } \\
\text { case law }\end{array}$ & $\begin{array}{l}\text { e.g., analysis of legislation } \\
\text { relevant to qualification of a } \\
\text { criminal offence }\end{array}$ & $\begin{array}{l}\text { A } \\
\text { B }\end{array}$ \\
\hline $\begin{array}{l}\text { Assessment of whether the } \\
\text { information provided is of legal } \\
\text { nature (complaint, request, } \\
\text { statement, etc.) }\end{array}$ & e.g., identifies the legal issue & $\begin{array}{l}\text { e.g., identifies article of the } \\
\text { Criminal Code to be used in } \\
\text { initiating to pretrial investigation }\end{array}$ & $\begin{array}{l}\text { A } \\
\text { B } \\
\text { C }\end{array}$ \\
\hline $\begin{array}{l}\text { Assessment which of the facts } \\
\text { presented are legally significant }\end{array}$ & $\begin{array}{l}\text { e.g., the legal significance of the } \\
\text { facts presented by the parties is } \\
\text { assessed, as well as their weight in } \\
\text { solving the legal problem }\end{array}$ & $\begin{array}{l}\text { e.g., the significance of the facts } \\
\text { gathered during the investigation } \\
\text { to support version of the event is } \\
\text { assessed }\end{array}$ & $\begin{array}{l}\text { A } \\
\text { B } \\
\text { C }\end{array}$ \\
\hline $\begin{array}{l}\text { Assessment of the weight, } \\
\text { persuasiveness and validity of } \\
\text { legally relevant facts and / or } \\
\text { arguments }\end{array}$ & $\begin{array}{l}\text { e.g., assessing, whether the ruling } \\
\text { would be rejected or modified by } \\
\text { higher court }\end{array}$ & $\begin{array}{l}\text { e.g., the significance of the facts } \\
\text { gathered in the case, the validity } \\
\text { of proving the (innocence) of the } \\
\text { suspect }\end{array}$ & $\begin{array}{l}\text { A } \\
\text { B } \\
\text { C }\end{array}$ \\
\hline $\begin{array}{l}\text { Selection, formulation, } \\
\text { correction of arguments for } \\
\text { preliminary / final position in the } \\
\text { case }\end{array}$ & $\begin{array}{l}\text { e.g., choosing arguments to justify } \\
\text { the ruling }\end{array}$ & $\begin{array}{l}\text { e.g., adjusting arguments when } \\
\text { drafting an indictment }\end{array}$ & $\begin{array}{l}\text { A } \\
\text { B } \\
\text { C }\end{array}$ \\
\hline $\begin{array}{l}\text { Assessment of whether the } \\
\text { formed position complies with } \\
\text { the basic principles of law }\end{array}$ & $\begin{array}{l}\text { e.g., whether the decision in the } \\
\text { case appears morally correct }\end{array}$ & $\begin{array}{l}\text { e.g., whether the decision as to } \\
\text { the guilt of the suspect appears } \\
\text { morally correct }\end{array}$ & $\begin{array}{l}\text { A } \\
\text { B } \\
\text { C }\end{array}$ \\
\hline $\begin{array}{l}\text { Decision to initiate (pre)trial } \\
\text { proceedings }\end{array}$ & $\begin{array}{l}\text { e.g., the decision about the } \\
\text { jurisdiction and admissibility of the } \\
\text { case }\end{array}$ & $\begin{array}{l}\text { e.g., decision to start pretrial } \\
\text { investigation }\end{array}$ & $\begin{array}{l}\text { A } \\
\text { B } \\
\text { C } \\
\text { D }\end{array}$ \\
\hline $\begin{array}{l}\text { Examination of the case during } \\
\text { (pre)trial proceedings, making } \\
\text { various intermediate decisions }\end{array}$ & $\begin{array}{l}\text { e.g., chairing the court hearing, } \\
\text { deciding about requests }\end{array}$ & $\begin{array}{l}\text { e.g., coordination of pretrial } \\
\text { investigation, rejecting the } \\
\text { versions of the event raised by } \\
\text { the defense }\end{array}$ & $\begin{array}{l}\text { A } \\
\text { B } \\
\text { C } \\
\text { D }\end{array}$ \\
\hline $\begin{array}{l}\text { Preparation of preliminary / final } \\
\text { position in the case (decision), } \\
\text { its correction, adjustment }\end{array}$ & $\begin{array}{l}\text { e.g., draft / final document of a } \\
\text { ruling }\end{array}$ & $\begin{array}{l}\text { e.g., draft / final document of an } \\
\text { indictment }\end{array}$ & $\begin{array}{l}\text { A } \\
\text { B } \\
\text { C } \\
\text { D }\end{array}$ \\
\hline
\end{tabular}

Notes. $A$-information acquisition, $B$ - information analysis, $C$ - decision selection, $D$-decision implementation.

When applied to major legal activities related to (pre)trial, our adapted LOA (see Table 1) provides more insight into legal decision making. Full table of legal activities with corresponding automation levels cannot be presented in this paper, thus the main insights are listed: 1) legal activities are predominantly complex -8 out of 10 activities involve 3 or 4 stages of the decision making; 2) information processing in information acquisition and analysis stages forms the basis of legal activities; 3) all of the higher decision making stages encapsulate all of the previous decision making stages (e.g., to be able to select the most relevant argument, one has to identify it, and analyze it); 4) the most complicated human-automation interaction occurs in the intermediate levels of automation through all stages of decision making and all legal activities; 5) most of the existing LegalTech is centered around 
information search, analysis, and document automation (to an extent) with some exceptions, e.g., Brazil courts, where algorithms provide relevant arguments with proposed wordings; 6) humans give up outcome control in the $4^{\text {th }}$ (high) automation level, and this might be the threshold level of trust lawyers could be willing to place in LegalTech.

Further, based on judicial intuition (Richards, 2016) and rationality theorizing (Ronkainen, 2011), the hybrid model (Bago \& De Neys, 2020) was updated to accommodate task difficulty levels (easy, intermediate, hard). The difficulty levels are important both to automation and information processing, as decision making in easy cases is thought to be easily automated in comparison to difficult, new cases; and more legal-experience-based intuition is thought to be used more in easy as opposed to difficult cases. In the adaptation of hybrid default-interventionist model used in this paper, levels of difficulty are defined in terms of conflict among initial intuitive responses. The "logical" intuition (Bago \& De Neys, 2020), in legal decision making would be the "legal" intuition. In this paper an intermediate level is proposed to include all hybrid model propositions about rational information processing (see Table 3).

Table 3. Dual processing model in legal decision making.

\begin{tabular}{|c|c|c|c|c|}
\hline \multirow{2}{*}{$\begin{array}{l}\text { Information } \\
\text { processing phase }\end{array}$} & \multirow{2}{*}{$\begin{array}{l}\text { Information } \\
\text { processing } \\
\text { type }\end{array}$} & \multicolumn{3}{|c|}{ Task difficulty level } \\
\hline & & Easy & Intermediate & Hard \\
\hline $\begin{array}{l}\text { Phase 1: Initial } \\
\text { response generation }\end{array}$ & Intuitive & $\begin{array}{l}\text { Strong legal / } \\
\text { heuristic decision } \\
\text { alternative comes } \\
\text { to mind (legal } \\
\text { intuition) (e.g., it is } \\
\text { clear who should } \\
\text { win the case), there } \\
\text { might be a weak } \\
\text { heuristic /legal } \\
\text { intuition (T1a) }\end{array}$ & $\begin{array}{l}\text { Several legal decision } \\
\text { alternatives (legal } \\
\text { intuitions) come to } \\
\text { mind, there can also be } \\
\text { one or more heuristic } \\
\text { alternatives (e.g., the } \\
\text { final ruling may be } \\
\text { nuanced) (T1b) }\end{array}$ & $\begin{array}{l}\text { Either no legal decision } \\
\text { alternatives come to mind } \\
\text { or several strongly } \\
\text { competing ones arise, } \\
\text { strong heuristic intuitions } \\
\text { are also possible (e.g., } \\
\text { euthanasia case, where } \\
\text { there is lots of emotional } \\
\text { investment, legal } \\
\text { circumstances may vary) } \\
\text { (T1c) }\end{array}$ \\
\hline $\begin{array}{l}\text { Phase 2: Conflict } \\
\text { monitoring }\end{array}$ & & None & Intermediate & Strong \\
\hline $\begin{array}{l}\text { Phase 3: Final } \\
\text { response } \\
\text { selection/generation }\end{array}$ & Rational & $\begin{array}{l}\text { The conflict is not } \\
\text { detected, legal } \\
\text { intuition is } \\
\text { accepted with } \\
\text { superficial } \\
\text { analytics (T2a) }\end{array}$ & $\begin{array}{l}\text { The conflict is } \\
\text { detected, but the first } \\
\text { (strongest) legal } \\
\text { intuition is rationalized } \\
\text { and/or justified without } \\
\text { considering other } \\
\text { alternatives (T2b). If } \\
\text { conflict detection fails, } \\
\text { the response is T2a. }\end{array}$ & $\begin{array}{l}\text { The conflict is detected, } \\
\text { and decoupling is } \\
\text { initiated: either initial } \\
\text { strongest intuition is } \\
\text { suppressed in the favor of } \\
\text { the second / subsequent } \\
\text { strongest intuition, or } \\
\text { alternative response is } \\
\text { generated that represents } \\
\text { novel response (T2e) }\end{array}$ \\
\hline
\end{tabular}

Finally, the decision making stages (not related to any specific legal activity), automation levels and information processing features were merged. Full table of results cannot be presented, but the main insights are provided: 1) as the difficulty of the task rises, the conflict among intuitions becomes more prominent - the legal intuitions weaken or compete with each other more, and heuristic intuitions become more significant; 2) the inner conflict among intuitions may heavily rely on the experience of the lawyer in dealing with the particular task; 3) the requirement state reasons for decisions has a twofold function: it may change T2 response in decision implementation stage of decision making, because at manual to intermediate levels of automation the human-lawyer will be obligated to rationalize and justify his/her decision; however, 4) the same requirement does not eliminate the possibility of bias, as rationalization (and justification) is a T2 response which does not require in-depth information processing (T2b, see Table 3); 5) automation may decrease and/or increase the conflict between initial intuitive responses, activating different T2 processes accordingly, depending on the congruence between human and algorithm decision alternatives; 6) the initial "legal" intuition would be selected as final response, if it is flawed, so will be the decision outcome, enabling bias occurrence at any stage of decision making; 7) if decision maker is not required to and/or has no motivation to search and analyze given or additional information, the decision selection stage may be performed without information acquisition and analysis stages. 


\section{Discussion and limitations}

The study provides some groundwork for analyzing human-automation interaction in legal decision making related to (pre)trial. Considering automation of legal decision making, it becomes clear that automation should be implemented after considering decision making stages and information processing features. For example, on the one hand, automation in information acquisition and analysis stages might reduce the cognitive load for human-lawyers, minimize the efforts needed to perform the activity, on the other hand it might reinforce decision biases, as they occur during initial stages of decision making and information processing. Moreover, automation may increase cognitive load in cases were conflicting decision alternatives are provided. Cognitive load is related to T2 processing (Evans, 2019) - less time, more pressure, more alternatives might mean less effective T2 processing. Notwithstanding, popular information search and analysis tools in legal arena usually provide suggestions which may correct the strong, potentially biased first legal intuition. Therefore, automation should be implemented considering changes intuitive and rational information processing, especially in the first stages of decision making.

It should be noted that the 10 activities presented here do not and possibly cannot encompass the immense diversity of the processes and decisions judges and prosecutors carry out in different types of cases and courts; likewise, the categorization cannot encapsulate possible differences among legal systems. However, the categorization of legal activities according to decision making stages provides a tangible basis to investigate automation and information processing.

Additionally, although the hybrid default-interventionist model (e.g., Bago \& De Neys, 2020) is not yet fully empirically validated, the propositions of the model can be fruitfully used in analysis legal decision making, as it was done previously using more traditional default-interventionist models (e.g., Ronkainen, 2011).

\section{Acknowledgements}

This project has received funding from European Social Fund (project No 09.3.3-LMT-K-712-19-0116 under grant agreement with the Research Council of Lithuania (LMTLT).

\section{References}

Bago, B., \& De Neys, W. (2020). Advancing the specification of dual process models of higher cognition: a critical test of the hybrid model view. Thinking \& Reasoning, 26(1), 1-30. doi: 10.1080/13546783.2018.1552194

De Neys, W. (2018). Bias, conflict, and fast logic: Towards a hybrid dual process future? In W. De Neys (Ed.), Current issues in thinking and reasoning. Dual process theory 2.0 (p. 47-65). Routledge/Taylor \& Francis Group.

Evans, J. St. B. T. (2019). Reflections on reflection: the nature and function of type 2 processes in dual-process theories of reasoning. Thinking \& Reasoning, 25(4), 383-415. doi: 10.1080/13546783.2019.1623071

Kahneman, D. (2011). Thinking, fast and slow. New York: Farrar, Straus and Giroux.

Morison, J., \& Harkens, A. (2019). Re-engineering justice? Robot judges, computerised courts and (semi) automated legal decision-making. Legal Studies, 39(4), 618-635. doi:10.1017/1st.2019.5

Parasuraman, R., Sheridan, T. B., \& Wickens, C. D. (2000). A model for types and levels of human interaction with automation. IEEE Transactions on Systems, Man, and Cybernetics - Part A: Systems and Humans, 30(3), 286-297. doi: 10.1109/3468.844354

Pennycook G., Fugelsang J. A., \& Koehler D. J. (2015). Everyday Consequences of Analytic Thinking. Current Directions in Psychological Science, 24(6), 425-432. doi:10.1177/0963721415604610

Proud, R.W., Hart, J. J., \& Mrozinski, R. B. (2003). Methods for determining the level of autonomy to design into a human spaceflight vehicle: a function specific approach. In: Performance Metrics for Intelligent Systems (PerMIS'03). NIST

Richards, D. (2016). When Judges Have a Hunch: Intuition and Experience in Judicial Decision-Making. Archiv fur Rechts- und Sozialphilosophie, 102(2), 245-60. doi: 10.2139/ssrn.2009883

Ronkainen, A. (2011). Dual-process cognition and legal reasoning. In M. Araszkiewicz, M. Myška, T. Smejkalova, J. Šavelka, \& M. Škop (Eds.), Argumentation 2011: International Conference on Alternative Methods of Argumentation in Law (pp. 1-32). Brno: Masaryk University. Retrieved from https://ssrn.com/abstract $=2004336$

Vagia, M., Transeth, A. A., \& Fjerdingen S. A. (2016). A literature review on the levels of automation during the years. What are the different taxonomies that have been proposed? Applied Ergonomics, 53, 190-202. doi: 10.1016/j.apergo.2015.09.013 